\title{
ACCIDENTAL PERFORATION OF THE RECTUM
}

\author{
By H. L. Frankel, M.B., M.R.C.P. \\ National Spinal Injuries Centre, Stoke Mandeville Hospital, \\ Aylesbury, Bucks., England
}

PeRforation of the rectum is one of the rarer complications of paraplegia. Perforation by a sigmoidoscope is described by Nyquist and Bors (1968) and the danger of sigmoidoscopy is mentioned by Leon (I97I). The danger of enemas has been mentioned (Frankel, 1967).

\section{CASE REPORTS}

The main clinical details are shown in the Table.

Patient I. During sigmoidoscopy perforation was suspected but not confirmed, when the sigmoidscope was at $20 \mathrm{~cm}$. The patient who had a complete flaccid lesion below T9 segment immediately complained of slight burning pain in the region of the umbilicus. The patient was closely observed and 2 hours later complained of a generalised lower abdominal pain made worse on palpation. Bowel sounds ceased after 5 hours and he had severe upper abdominal pain with guarding in the innervated area. He started to vomit. At operation after 7 hours there was faeces in the peritoneum with early peritonitis. A tear about $I$ in. long on the anterior surface of the recto-sigmoid junction was closed by sutures in two layers. A pelvic drain was left in and he was given penicillin and streptomycin. Post-operatively he developed an abscess in the abdominal wall and after this had been drained he recovered uneventfully.

Patient 2. This was a woman of 40 with a $T_{5}$ lesion who was remarkable in that she had had 12 children. Her rectum was perforated in the course of a digital evacuation. Slight bleeding was investigated by immediate sigmoidoscopy which confirmed the perforation. She had no symptoms and was operated on I hour later. A I in. perforation of the anterior wall of the upper rectum was closed in two layers, the pelvis was drained, she was given penicillin and streptomycin and made an uneventful recovery.

Patient 3. This patient was being given a pre-operative soap and water enema (she was due to have an operation on a pressure sore). During the enema she complained of spasm and pain in the upper abdomen-Fifteen minutes later she vomited. As she had a similar pain during an enema 6 months previously, the significance of the symptoms was not at first appreciated. She rapidly became shocked and pulseless and could not be resuscitated sufficiently to render her fit for operation. She died I4 hours after the enema.

At post-mortem there was a large quantity of soapy fluid in the peritoneum and signs of peritonitis, surprisingly no defect could be found in the rectum. Histology showed no evidence of amyloidosis.

Patient 4. This man had taken small doses of prednisolone for 7 years to control subacute hepatitis. He lived near the hospital and was given a soap and water enema by the District Nurse. During the enema he complained of severe epigastric pain radiating to his back and shoulders. The enema produced a large amount of formed 
faeces and some blood. He was admitted to hospital where he was found to have a distended silent abdomen with marked tenderness above the level of his lesion (T8). At laparotomy 6 hours after the enema the peritoneal cavity was full of 'dirty dishwaterlike fluid'. There was some bruising of the sigmoid about $25 \mathrm{~cm}$. above the anus but no perforation was found. A transverse colostomy was performed and the pelvis drained. Post-operatively he developed acute renal failure and he died 2 weeks later (his renal function had previously been impaired. Creatinine clearance $37.5 \mathrm{ml} . /$ minute).

At post-mortem there was a pelvic abscess over a lightly sealed-off perforation. Histology showed some amyloidosis in the spleen, thyroid and kidneys but none in the rectum.

Patient 5. This patient was also being given a pre-operative soap and water enema (she was due to have a nephrolithotomy). During the enema she complained of severe abdominal pain radiating into both shoulders, her bowel sounds were at first present but later the abdomen became silent. At operation 4 hours later the peritoneum was full of 'dirty watery fluid'. The perforation could not be found. A transverse colostomy was performed and the pelvis drained. She did not want to have the colostomy closed.

TABLE

\begin{tabular}{|c|c|c|c|c|c|}
\hline Age & Lesion and & Juration & $\begin{array}{l}\text { Cause of } \\
\text { perforation }\end{array}$ & Operation & Result \\
\hline $\begin{array}{l}38 \\
\text { Male } \\
40 \\
\text { Female } \\
\quad \text { (12 children) } \\
64 \\
\text { Female } \\
60 \\
\text { Male } \\
\quad \text { (prednisolone) } \\
38 \\
\text { Female }\end{array}$ & $\begin{array}{l}\text { T9 complete } \\
\text { flaccid } \\
\text { T5 complete } \\
\text { spastic } \\
\text { Tro complete } \\
\text { spastic } \\
\text { T8 complete } \\
\text { flaccid } \\
\text { T6 complete } \\
\text { spastic }\end{array}$ & $\begin{array}{l}\text { I year } \\
2 \text { years } \\
\text { 12 years } \\
7 \text { years } \\
\text { I2 years }\end{array}$ & $\begin{array}{l}\text { Sigmoidoscopy } \\
\text { Digital } \\
\text { Enema in } \\
\text { hospital } \\
\text { Enema at home } \\
\text { Enema in } \\
\text { hospital }\end{array}$ & $\begin{array}{l}7 \text { hours. Repair } \\
\text { and drainage } \\
\text { I hour. Repair } \\
\text { and drainage } \\
\text { None } \\
6 \text { hours. Drainage } \\
\text { and colostomy } \\
4 \text { hours. Drainage } \\
\text { and colostomy }\end{array}$ & $\begin{array}{l}\text { Recovered } \\
\text { Recovered } \\
\text { Died after I4 } \\
\text { hours } \\
\text { Died after } 2 \\
\text { weeks of renal } \\
\text { failure } \\
\text { Recovered. Still } \\
\text { has colostomy } \\
\text { after } 5 \text { years }\end{array}$ \\
\hline
\end{tabular}

\section{DISCUSSION}

In view of the large number of enemas given and the much larger number of digital evacuations performed it is surprising that the complication is so rare. The mechanism of the large perforations found in the first two cases is clear, but the mechanism of the entry of fluid in the cases following enemas is more difficult to understand. In two cases no perforation could be found at operation and in patient number 3 the perforation could not even be detected at post-mortem. It is possible that forceful, digital evacuations may quite frequently cause minor defects in the rectal mucosa, this may be of little consequence unless they are followed by fluid underpressure. It is also possible that the defect is caused by the insertion of the rectal tube.

Enemas may sometimes cause abdominal pain, vomiting and signs of shock and the patient may then recover spontaneously. Presumably these patients have not sustained a perforation. All such patients must be closely and urgently observed and preparation made for immediate surgery if their lives are to be 
saved. The most reliable sign of perforation has been shoulder tip pain made worse by abdominal palpation.

\section{SUMMARY}

Five paraplegic patients with traumatic perforations of the rectum are described. One was caused by sigmoidoscopy, one by digital evacuation and three by enemas. Two patients died. The causes and treatment are described and discussed.

Acknowledgements. I am grateful to Dr. J. J. Walsh who performed the first two operations, Mr. G. Hyslop who performed the second two operations and to Dr. Joan Rivett who performed the post-mortem examinations.

\section{REFERENCES}

Frankel, H. L. (1967). Int. F. Paraplegia, 4, 254.

LEON, H. (I97I). Proceedings of I8th Veterans Administration Spinal Cord Injury Conference, p. 226.

Nyquist, R. H. \& Bors, E. (1968). Int. F. Paraplegia, 5, 22. 